УДК 551.42.054

\title{
ECOLOGICAL MONITORING IN THE REGION OF AKADEMIK VERNADSKY ANTARCTIC STATION
}

\author{
S.B.Bondar ${ }^{1}$, I.G.Orlova ${ }^{1}$, Yu.I.Popov ${ }^{1}$, V.V.Ukrainsky ${ }^{1}$, V.P.Usenko ${ }^{2}$ \\ ${ }^{1}$ Ukrainian Scientific Centre of the Ecology of Sea, Odessa \\ ${ }^{2}$ Institute of Geological Science of National Academy of Ukraine, Kiev \\ accem@te.net.ua/Fax 0482 63-72-00
}

\begin{abstract}
The issues of organization and carrying out of ecological monitoring in the region of the Ukrainian Antarctic Station "Akademik Vernadsky" are taken up in the report. The information about the basic circulation flows, temporal (daily and annual) and spatial changeability of hydrological \& hydrochemical ingredients as well as the vertical hydrological \& hydrochemical water structure are presented on the basis of 1997-1998 experimental data. The description of the modern state of the chemical pollution of the basic elements of the Argentina Archipelago Islands' shallow water ecosystem. The broad spectrum of pollutants, such as different components of oil pollution, including carcinogenic polyaromatic hydrocarbons, highly toxic chlorinated hydrocarbons, heavy metals have been found in the majority of the ecosystem`s elements under analysis. The local areas of oil pollution have been found in the region of Galindez Isles. The obtained results are the part of the experimental data base for solving fundamental and applied problems including the problem of environmental protection. It is necessary to continue such investigations for studying the tendencies, for forecasting the vulnerable Antarctic ecosystems' state and for working up measures to protect ecosystems from the further pollution.
\end{abstract}

Key words: Antarctic, station “Akademik Vernadsky”, monitoring, ecosystem, pollution

Екологічний моніторінг у районі антарктичної станції Академік Вернадський. С.Б.Бондар, І.Г.Орлова, Ю.І.Попов, В.В.Український, В.П.Усенко

Реферат. У доповіді розглянуті питання організації і виконання екологічного моніторингу в районі української антарктичної станції Академік Вернадський. На основі експериментальних даних 1997-1998 рр. представлені дані про основні циркуляційні потоки, тимчасову (добову, міжрічну) і просторову мінливість гідролого-гідрохімічних інгредієнтів, вертикальну гідролого-гідрохімічну структуру вод. Наведено характеристику сучасного стану хімічного забруднення основних елементів екосистеми шхерного мілководдя. У більшості аналізованих елементів екосистеми виявлений широкий спектр забруднюючих речовин: різні компоненти нафтового забруднення, включаючи канцерогенні поліароматичні вуглеводні, високотоксичні хлоровані вуглеводні, важкі метали. Виявлено локальні ділянки нафтового забруднення в районі острова Галіндез. Отримані результати є частиною експериментальної бази даних для рішення фундаментальних і прикладних, у тому числі природоохоронних задач. Продовження цих досліджень необхідно для вивчення тенденцій, прогнозування стану уразливих антарктичних екосистем і розробки заходів щодо запобігання їхнього подальшого забруднення.

The concept of the development of the Antarctic Continent as territory, which is especially protected, is formulated in the Protocol on Protection of the natural environment (1991 p.), which was ratified by Ukraine in 2001. According to item 3.1 of the Protocol any activity in the Antarctic Continent (including scientific) should be accompanied with the estimation of its influence on the environmental natural environment.

Recently a number of tourist sea yachts and passenger courts, which visit the most accessible and rather favorable in the climatic attitude areas of the Antarctic Region has increased considerably. It concerns the Argentina archipelago, which is located to the northwest from the Antarctic Peninsula, where Ukrainian Antarctic station (UAS) Akademik Vernadsky is based. It results in the increase of the anthropogenous loading on these areas of the Antarctic Region.

The area of shelf waters of islands of the Argentina archipelago practically is not investigated. During last 15 years a number of large-scale foreign research programs of the Antarctic marine ecosystem has been carried out (Smith et al., 1995). The major part of observations has covered the zone of the Antarctic US station "Palmer". However, none of the programs treated the chemical pollution that is well known by its pernicious influence on marine ecosystems. It is especially 
hazardous for "vulnerable" Antarctic ecosystems. Due to the already existing anthropogenous factor of the UAS area and the neighbouring water areas require the constant geoecosystem researches (Godzik et al., 1997).

The first reconnoitring investigations of this geoecosystem were carried out during the first marine expedition (1997) and significantly extended during the second expedition (1998) (Bondar et al., 2000). Starting with spring 2001 in the framework of the ecological program under the initiative and with the technical assistance of the UkrSCES the regular hydrophysical observations were begun.

The aim of the investigations was the complex studying of the marine ecosystem condition in the UAS and nearby water zone with following scientific monitoring in order to appreciate the anthropogenic and climatic changes therein. The study of the ecosystem chemical pollution levels was one of the basic scientific goals. The complex experiment included hydrophysical, hydrochemical and meteorological observations as well as the observations of the chemical pollution of the ecosystem basic components.

The current observations and study of the role of hydrodynamic factors in the processes of transfer and dispersion of polluting microimpurities in five points of the water area were studied by the means of autonomous buoy stations. In order to determine the impact of tidal currents on the hydrological and hydrochemical water structures, two long-term stations were performed. To determine the spatial variability of the basic parameters at 10 stations, the complex observations of hydrological, hydrochemical, hydrobiological and hydrometeorological parameters and sampling of pollutants were made. Background chemical pollution levels were selected and a series of water, bottom sediments and hydrobionts analyzed. It is necessary to emphasize that such detailed investigations have been carried out in this area for the first time.

The steady two-layer vertical stratification of the thermohaline, kinematics and hydrochemical characteristics with waters partition in the layer of 30-35 m was revealed. At depths less than $30 \mathrm{~m}$ the surface structure was only observed. The water temperature increased from the surface down to the depth of the layer of the basic hydrophysical characteristics jump and further decreased with depth. The salinity increased with the depth everywhere.

The tidal activity is the significant factor of the variability of the hydrophysical and hydrochemical characteristics. The analysis of the temporal variations of vertical distribution of these parameters revealed distinct daily and semi-diurnal tidal harmonics.

The waters motion in the surface structural zone was put into effect mainly in the northern direction with the average speed $4 \mathrm{~cm} / \mathrm{sec}$; in the bottom structure the southward motion with about the same speed was observed. Generally the speeds of tidal currents did not exceed $10 \mathrm{~cm} / \mathrm{sec}$ and were comparable with those of residual currents. Maximal current speeds observed were equal to 15$18 \mathrm{~cm} / \mathrm{sec}$. The presence of multidirectional flows points to compensatory character of the bottom currents in this area.

The more detailed data both on the spatial and temporary variability of hydrophysical and hydrochemical parameters are given in (Bondar et al., 1998, Bulgakov et al., 1999, Ukrainsky et al., 1998, Ukrainsky et al., 1998). The results on atmospheric chemistry observations are submitted in (Lepeshkin, 1998).

It is necessary to emphasize, that during 1997 - 1998 in the area under research the rather high content of the ammonium nitrogen and others biogenic substance was marked, pointing to the high biogenic water pollution (Bondar et al., 2000). A source of the pollution is the crude waste UAS water and has a local character. In summer 2000-2001 the intensive development of seaweed and flowering of waters on the sea water area of the Argentina archipelago was observed being evidence of waters eutrophication.

In the same period the anomalies of thermal mode of the thermohalinic characteristics of the coastal waters were found (Figure). The water temperature reached $4-5{ }^{\circ} \mathrm{C}$ in this period. Thus it was revealed the intensive dissolution of surface waters caused by iceberg and glaciers throwing. The sharp two-layer structure was observed in vertical distribution of the thermohalinic characteristics. The speeds of mainly southward currents in the bottom structural zone did not exceed $10 \mathrm{~cm} / \mathrm{sec}$. Such climatic conditions in Antarctic summer may give rise to the oxygen mode deterioration. 
Simultaneously with biogenic pollution of local sites of the water area a number of chemical pollutants were revealed in the analyzed water samples, bottom sediments and various hydrobionts (Bondar et al., 2000).
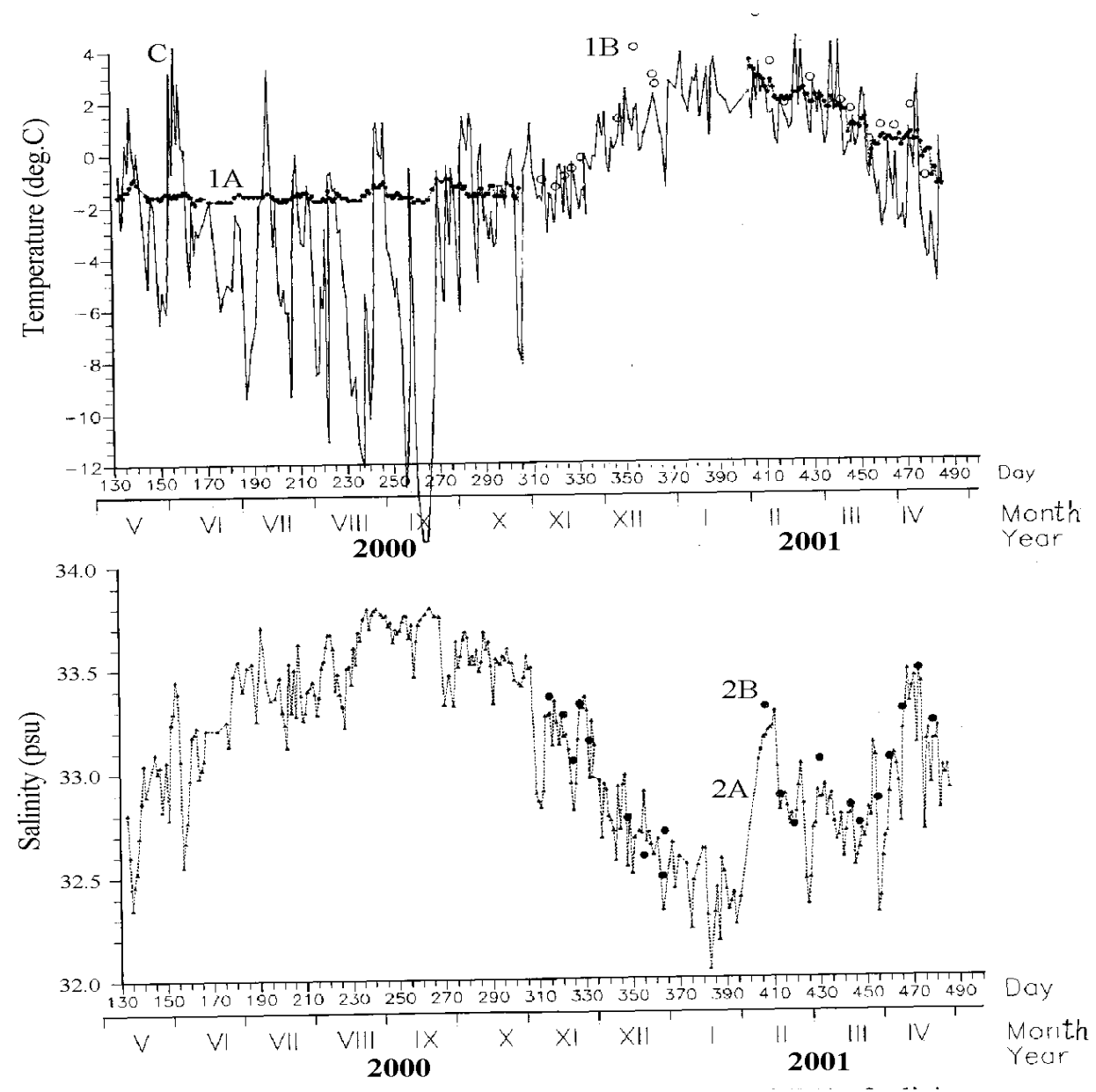

Figure. Annual cycles - of the temperature (1A) and salinity $(2 \mathrm{~A})$ in the coastal zone at the water registration station; temperature (1B) and salinity (2B) in the surface layer according to byoceanographic station data and air temperature $(\mathrm{C})$ at Akademik Vernadsky station.

It was found the rather low level for $\mathrm{AD}$ found only in proximity to the source (crude waste water) near Galindez island (up to $20 \mathrm{mkg} / \mathrm{l}$ ). Near Mordvinov island concentration of AD was close to the background value $(5.2 \mathrm{mkg} / \mathrm{l})$, but in the Southern Orkney islands water area these substances were not found.

In spite of the fact that heavy metals are not used at the station (Videnina et al., 1977) their content is rather high. The maximal concentration of heavy metals was found in the samples taken near the Yahtovaya bay and the berth on Galindez island; minimal concentration - in the inter-island zone at the buoy station near Skua island.

The rather high level of chlorinated hydrocarbons (DDT, PCB) close to that in some areas of the World Ocean was also registered (Orlova, 1992, Subramanian et al., 1983).

The various components of petroleum pollution are the most widely distributed in the ecosystem under study. The maximal oil pollution of the bottom sediments (saturated hydrocarbons, aromatic hydrocarbons and 3,4-BP) was revealed in samples taken in proximity of the Yahtovaya Bay and the berth of Galindez Island. Especially it is necessary to emphasize on the occurrence of heavy 
saturated hydrocarbons and 3,4-BP pollution with concentrations $(246 \mathrm{mg} / \mathrm{kg}$ and $39 \mathrm{mkg} / \mathrm{kg}$ accordingly) reached up to the level of the polluted zones of the World Ocean.

Besides in the samples of the bottom sediments a number of individual polycyclic aromatic hydrocarbons-PAN was found using mass- chromass-spectrometric technique (Bondar et al., 2000).

To reveal the origin of oil pollution, analysis of water samples (from the berth and anchorage), snow samples (from the spillage area) and diesel fuel used at the station was made using the same technique. The identity of peaks on spectrograms allows concluding that the diesel fuel spillage to the adjacent water area is one of the sources of oil pollution. At the same time the distribution of nalkanes found out in the samples permits to conclude that the heavy fractions of hydrocarbons (hydrocarbons with high values of C-atoms) were presented in these samples. This oil pollution probably relates with "old" oil spillage in 1992.

Analyzing experimental we can conclude that the ecological situation near Akademik Vernadsky station is rather hard due to, firstly, the water eutrophication with the negative intensive waters flowering with following oxygen regime deterioration and, secondly, the quite high level of chemical pollution of the shelf ecosystem of the Argentina Archipelago Islands. The last may be caused by the global character of the stable pollutants distribution as well as by the influence of constant spot sources of pollution such as the coastal one, which remains after the fuel tank breakage, and navigation increased from year to year in summer. The low speeds of chemical and biological degradation of pollutants are an additional source.

\section{References.}

Bondar S.B., Orlova I.G. Some results of the complex ecology monitoring in the Akademik Vernadsky station region // Bull. UAC, 1998. -2. -P.160-171.

Bondar S.B., Orlova I.G., Usenko V.P. Ingredients of chemical pollution in the ecosystem shallow waters of the Argentine Archipelago (area of the Ukrainian Antarctic station Akademik Vernadsky) // Bull. UAC., 2000. Is. 3. -P.192-208.

Bulgakov M.P., Orlova I.G., Ukrainsky V.V. et al. Results of oceanographishe investigations in the Akademik Vernadsky antarctic station region on the results seconds Ukrainian seas antarctic expedition. Report NAS of Ukraine, 1999, N 2, -P.118-121.

Videnina N.G., Rybachuk V.P. Referring to evolution of the Akademik Vernadsky station Effect Upon the Environment // Bull. UAC. 1997. Is. 1. -P.160-177.

Gozhic P.F., Usenko V.P. Some aspects of Investigation of the Geoecosystem of the Aquatoria of Argentine Island Archipelago // Bull. UAC., 1997. Is. 1. -P.217-227.

Lepyashkin V.I. Ionic component of the atmospheric aerosol in the region of the South Orkney and South Scotland Islands // Bull. UAC, 1998. Is. 2. -P.25-28.

Orlova I.G. Chlorinated Hydrocarbons in Marine Ecosystems. S-Petersburg. Hydrometeoizdat. 1992. -107 p.

Ukrainsky V.V., Popov Y.I., Neverovsky I.P. et al. Structura and variability of thermohaline field and kinematic characteristics of the waters of the arhipelago Argentine islands in march 1988 // Bull. UAC. Is. 2., 998, -P.102-110.

Ukrainsky V.V., Popov Y.I., Neverovsky I.P. et al. Kinematic of the currents and the vertical water structure of the Argentine islands on the basis if the oceanographic observations // Bull. UAC. Is. 2., 1998. -P.102-110.

Kari D.M. RASER - Research on Antartic coastal rates. Part A - Oceanographic Research Papers. Deep-Sea Res. 38, 1991. -P.1029-1055.

Smith Raymond C., Karen S., Baker et al. The Palmer LTER: A Long-term Ecological Research Program at Palmer Station, Antartica // Oceanography, vol. 8, № 3. 1995. -P.77-85.

Subramanian B.R., Shinsuke Tanabe, Hideo Hidaka, and Ryo Tatsukawa. DDTs and PCB Isomers and Congeners in Antartic Fish // Arch. Environ. Contam. Toxicol // V. 12. 1983. -P.621-626. 